\title{
Az SGLT-2-gátló és a duális SGLT-2/SGLT-1- gátló készítmények potenciális helye az 1-es típusú diabetes terápiájában
}

\author{
Jermendy György dr.
}

\begin{abstract}
Osszefoglalás
Az 1-es típusú diabetesben szenvedök antihyperglykaemiás kezelését inzulin adása jelenti. A 2-es típusú diabetes kezelésére kifejlesztett új antidiabetikumokkal kapcsolatban számos esetben megvizsgálták az új készitmények hatásosságát és biztonságosságát 1-es típusú diabetesben is. Mind ez ideig (2018 végéig) egyetlen orális antidiabetikumot vagy injektábilis, nem-inzulinszerü készitményt sem regisztráltak 1-es típusú diabetes kezelésére. Az SGLT-2-gátló készitmények a 2-es típusú diabetes kezelésére szolgálnak monoterápiában vagy kombinációs kezelésben. Több klinikai vizsgálatot végeztek dapagliflozinnal és empagliflozinnal 1-es típusú diabetesben is (DEPICT, EASE), a készitményt az inzulinterápia kiegészitéseként adva. A sotagliflozin regisztráció elött álló orális antidiabetikum, az SGLT-2 és SGLT-1 duális gátlását biztositja. A sotagliflozinnal végzett klinikai vizsgálatok (inTandem) a készitmény alkalmazhatóságát 1-es típusú diabetesben tesztelték. Az eddigi vizsgálatokigazolták az SGLT-2-gátlók és az SGLT-2/SGLT-1 duális gátló hatékonyságát 1-es típusú diabetesben is. A regisztrált biztonságossági adatok között azonban a diabeteses ketoacidózis-esetek megszaporodása ritka, de potenciálisan súlyos mellékhatásként értékelendö. A közlemény azokat a klinikai tanulmányokat tekinti át, amelyeket dapagliflozinnal, empagliflozinnal és sotagliflozinnal végeztek 1-es típusú diabetesben, a készitményeket a zajló inzulinterápia mellett kiegészitö terápiaként alkalmazva.

Kulcsszavak: SGLT-2-gátlók, empagliflozin, dapagliflozin, sotagliflozin, 1-es típusú diabetes
\end{abstract}

\section{SGLT-2 and dual SGLT-2/SGLT-1 inhibitor adjunct therapy in type 1 diabetes}

Summary: Patients with type 1 diabetes should be treated with insulin. Nevertheless, the efficacy and safety of newly developed antidiabetic drugs for treating type 2 diabetes were investigated by several clinical trials in type 1 diabetes as well. Importantly, no oral or non-insulin injectable antidiabetic drugs were approved so far (by the end of 2018) in any country for treating type 1 diabetes. SGLT-2-inhibitors (dapagliflozin and empagliflozin in Hungary) can be used in monotherapy or in combination for treating patients with type 2 diabetes. In the last couple of years, randomized clinical trials were performed with dapagliflozin (DEPICT) or empagliflozin (EASE) in patients with type 1 diabetes. Sotagliflozin is a newly developed SGLT2/SGLT-1 dual inhibitor drug. Clinical trials with sotagliflzoin (inTandem) were completed in patients with type 1 diabetes, however, the approval procedure for registration of sotagliflozin as an adjunct treatment in patients with type 1 diabetes is still in progress. The efficacy of SGLT-2 and SGLT-2/SGLT-1 dual inhibitor drugs were documented in type 1 diabetes. Regarding safety, an increase in the diabetic ketoacidosis cases should be considered rare but potentially severe side-effect. In this article, clinical trials with dapagliflozin, empagliflozin and sotagliflozin as an adjunct therapy in patients with type 1 diabetes are reviewed.

Key words: SGLT-2-inhibitors, empagliflozin, dapagliflozin, sotagliflozin, type 1 diabetes

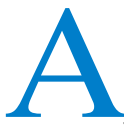
z 1-es típusú diabetesben szenvedők antihyperglykaemiás kezelését inzulin adása jelenti. Napjainkban a felnőtt betegek intenzív konzervatív inzulinterápiában részesülnek, a fiatal 1-es típusú betegek körében egyre inkább terjed a pumpakezelés. A humán inzulin széles körü elterjedése után az elmúlt mintegy másfél évtizedben az inzulinanalógok elérhetővé válása javította 
a betegek életminőségét és gyakran anyagcserehelyzetét is.

A 2-es típusú diabetes kezelésére kifejlesztett új antidiabetikumokkal kapcsolatban - amennyiben a hatásuk részben vagy egészben a béta-sejt-funkciótól függetlennek bizonyult - mindig felmerült az a gondolat, hogy az adott készítményt talán kiegészítő kezelésként alkalmazni lehet 1-es típusú diabetesben is. Az inzulinterápiával kapcsolatban jól ismert, hogy 1-es típusú diabetesben az anyagcserehelyzet elég gyakran elmarad a kívánatostól, a betegeket a hyperglykaemia késői következményei fenyegetik, de inzulinterápia mellett gondot jelent a hypoglykaemia-kockázat növekedése és a testsúly gyarapodása is. Érthető tehát az a törekvés, hogy a 2-es típusú diabetes kezelésére kifejlesztett antidiabetikumok potenciális alkalmazási lehetőségét a fejlesztés stádiumában az 1-es típusú diabetes terén is megvizsgálják akkor, ha az adott készítmény esetében az inzulinterápiát kiegészítő kedvező hatásra elméletileg számítani lehet.

$\mathrm{Az}$ előző gondolatok jegyében érdekes módon talán a legtöbbet a metformin szerepét tanulmányozták 1-es típusú diabetesben. ${ }^{1}$ Ennek oka az is lehet, hogy több évtizede ismert és használt, nem drága és az esetek döntő többségében jól tolerálható készítményről van szó. Az sem vitás, hogy a hazai gyakorlatban - bár off label indikációnak minősül 1-es típusú diabetesben - az inzulinterápia mellett alkalmazott metformin nem számít ritkaságnak. Erre leginkább felnőttkorú, hoszszú betegségtartammal és testsúlyfelesleggel rendelkező, nagyobb inzulinigényü betegek körében kerülhet sor., ${ }^{2,3} \mathrm{Az}$ 1-es típusú diabetesben adott metformin szerepét a közelmúltban a kardiovaszkuláris köztes végpontok (carotis-falvastagság) alakulása terén vizsgálták. A 2017-ben publikált REMOVAL vizsgálat azonban igen szerény eredménnyel zárult, az elsődleges végpont nem teljesült, a kezdeti $\mathrm{HbA}_{1 \mathrm{c}}$-csökkenés és testsúlyvesztés nem bizonyult tartósnak. ${ }^{4} \mathrm{Ez}$ az adat nem igazán támogatja azt a gondolatot, hogy 1-es típusú diabetesben - off label - érdemes lenne próbálkozni metformin adásával.

Az akarbóz napjainkban a 2-es típusú diabetes kezelésében Európa-szerte jelentősen háttérbe szorult, de elvileg még mindig alkalmazható. Szerepét 1-es típusú diabetesben közel két évtizede tanulmányozták, nem is alaptalanul, hiszen alkalmazásától a postprandialis vércukor csökkenése volt remélhető., ${ }^{5,6}$

A tiazolidindionok közé tartozó rosiglitazon és pioglitazon szerepét is vizsgálták humán körülmények között 1-es típusú diabetesben, szerény eredménnyel. ${ }^{7,8,9}$

Az új innovatív készítmények között a DPP-4gátló szitagliptint több tanulmányban tesztelték 1-es típusú diabetesben, illetve LADA-ban, meggyőző eredmény nélkül. ${ }^{10,11}$ A liraglutiddal folyt az ADJUNCT ONE vizsgálat 1-es típusú diabetesben, $\mathrm{s}$ bár a $\mathrm{HbA}_{1 \mathrm{c}}$-érték, a testsúly és az inzulindózis előnyösebben alakult (vs. placebo), a tüneteket okozó hypoglykaemia és a ketózis növekedése, továbbá a szerény glykaemiás hatékonyság nyomán az indikációbővítés nem látszott realitásnak. ${ }^{12}$

A 2-es típusú diabetes kezelésére kifejlesztett és forgalmazott készítmények 1-es típusú diabetesben betöltött potenciális szerepéről részletesebb adatok a közelmúltban publikált áttekintő közleményekben lelhetők fel. ${ }^{13,14,15,16}$ Le kell azonban szögezni, hogy jelenleg, a napi gyakorlatban, a 2-es típusú diabetes kezelésére regisztrált készítményeket csak az alkalmazási elöírás szerint, 2-es típusú diabetesben hasznosíthatjuk. Érdeklődésre tarthat azonban számot, hogy az SGLT-2-gátló készítményekkel (dapagliflozin, canagliflozin, empagliflozin) és az SGLT-2/SGLT-1 duális gátlását biztosító sotagliflozinnal milyen eredménnyel zárultak azok a klinikai vizsgálatok, amelyeket 1-es típusú diabetesben szenvedők körében folytattak.

\section{SGLT-2-gátlók az 1-es típusú diabetes terápiájában}

Az SGLT-gátlók között hazánkban néhány évvel ezelőtt először a dapagliflozin vált elérhetővé, majd röviddel utána az empagliflozin is a betegek rendelkezésére állt. A canagliflozin Európában (és így Magyarországon) regisztrált készítmény, de hazai forgalmazásától a gyártó cég elállt. Az ertugliflozin hazai bevezetésére 2019-ben számíthatunk. Az SGLT-2-gátlók inzulintól független, speciális hatása alapján rögtön az érdeklődés előterébe került, és a mai napig napirenden van, hogy van-e helyük kiegészítő kezelésként az 1-es típusú diabetes terápiájában. ${ }^{17,18,19,20}$ Klinikai vizsgálatok zajlottak - experimentális megfigyeléseket követően 
- 1-es típusú diabetesben SGLT-2-gátlókkal (dapagliflozin, empagliflozin, canagliflozin). Ezt az indikációs területet vizsgálva 2018 végén III. fázisú stádiumban néhány készítmény van, a canagliflozin klinikai vizsgálatával 1-es típusú diabetesben a II. fázisú vizsgálat után leálltak. A hatástani csoport 1-es típusú diabetesben történő alkalmazhatóságával kapcsolatban már csak azért is nagy az érdeklődés, mert ha bebizonyosodik, hogy ezek a készítmények hatásosak és ugyanakkor biztonsággal alkalmazhatók, akkor elméletileg több előnyre is számítani lehet. Várható a glykaemiás kontrollban történő javulás, de feltételezhető, hogy az SGLT-2-gátlók kardiovaszkuláris és renális kimeneteli események alakulására kifejtett kedvező hatása (amit 2-es típusú diabetesben már bizonyítottak) ebben a betegcsoportban is érvényesülhet.

\section{Dapagliflozin}

A DEPICT-1 kettős vak, placebo-kontrollos, a véletlen besorolás elvét követő, III-as fázisú vizsgálatot (Dapagliflozin Evaluation in Patients with Inadequately Controlled Type 1 Diabetes) 17 ország 143 vizsgálóhelyén végezték. ${ }^{21}$ A tanulmányba 18-75 év közötti, nem megfelelő glykaemiás kontrollú $\left(\mathrm{HbA}_{1 \mathrm{c}}: 7,7-11,0 \%\right)$, 1-es típusú diabetesben szenvedő és legalább 12 hónapja inzulinkezelésben részesülő betegeket vontak be. Nyolc hétre terjedő optimalizációs előperiódus után történt 1:1:1 arányban a randomizáció három ágra: 1) inzulin + napi $5 \mathrm{mg}$ dapagliflozin $(\mathrm{n}=277), 2)$ inzulin + napi $10 \mathrm{mg}$ dapagliflozin $(\mathrm{n}=296), 3) \mathrm{in}-$ zulin + placebo $(n=260)$.

A kiindulási $\mathrm{HbA}_{1 \mathrm{c}}$-érték a randomizációkor $8,53 \%$ volt. A betegek életkora 42 év, a diabetestartam 20 év volt, a betegek $60 \%$-a napi többszöri inzulinterápián volt, míg 40\%-uk pumpakezelésben részesült. Az inzulinterápia a helyi irányelveknek megfelelően történt, kötelező titrációs előírás nem volt, a dózist a vércukor-önellenőrzéssel mért értékek alapján a vizsgáló módosította, ha szükségesnek látta. Az elsődleges végpont a $\mathrm{HbA}_{1 \mathrm{c}}$-érték kiindulási helyzethez viszonyított változása volt (vs. placebo). A tanulmány tartama 24 hét volt. $\mathrm{A} \mathrm{HbA}_{1 \mathrm{c}}$-érték átlaga klinikailag jelentős mértékben csökkent a vizsgálat 24. hetére, statisztikailag értékelhetően csökkent a testsúly és a napi inzulindózis is. A hypoglykaemiás események gyakoriságát tekintve nem volt értékelhető különbség a három csoport között. A nemkívánatos mellékhatások terén a dapagliflozinnal kapcsolatban új körülmény nem merült fel, a mellékhatás-profil megfelelt a korábbról már ismertnek (1. és 2. táblázat).

A DEPICT-1 vizsgálat további 28 hétre történő kiterjesztésének eredményeit, az összesített 52 hetes vizsgálat adatait 2018 decemberében közölték. ${ }^{22}$

\section{1. táblázat. A DEPICT (dapagliflozin vs. placebo) és az EASE (empagliflozin vs. placebo) vizsgálatok fontosabb adatai}

\begin{tabular}{|c|c|c|c|c|}
\hline & DEPICT-1 & DEPICT-2 & EASE-2 & EASE-3 \\
\hline Alapterápia & optimalizált inzulin & optimalizált inzulin & optimalizált inzulin & optimalizált inzulin \\
\hline Vizsgálati készítmény & $\begin{array}{c}\text { placebo, } \\
\text { dapagliflozin } 5 \mathrm{mg}, \\
\text { dapagliflozin } 10 \mathrm{mg}\end{array}$ & $\begin{array}{c}\text { placebo, } \\
\text { dapagliflozin } 5 \mathrm{mg}, \\
\text { dapagliflozin } 10 \mathrm{mg}\end{array}$ & $\begin{array}{c}\text { placebo, } \\
\text { empagliflozin } 10 \mathrm{mg} \text {, } \\
\text { empagliflozin } 25 \mathrm{mg}\end{array}$ & $\begin{array}{c}\text { placebo, } \\
\text { empagliflozin } 2,5 \mathrm{mg}, \\
\text { empagliflozin } 10 \mathrm{mg} \text {, } \\
\text { empagliflozin } 25 \mathrm{mg}\end{array}$ \\
\hline Betegszám (n) & 833 & 813 & 730 & 977 \\
\hline Vizsgálat tartama & 52 hét* & 52 hét* & 52 hét** & 26 hét \\
\hline Elsődleges végpont & $\begin{array}{c}\mathrm{HbA}_{1 c} \text {-változás } \\
\text { (vs. placebo) a 24. héten }\end{array}$ & $\begin{array}{c}\mathrm{HbA}_{1 c} \text {-változás } \\
\text { (vs. placebo) a 24. héten }\end{array}$ & $\begin{array}{c}\mathrm{HbA}_{1 \mathrm{c}} \text {-változás } \\
\text { (vs. placebo) a 26. héten }\end{array}$ & $\begin{array}{c}\mathrm{HbA}_{{ }_{\mathrm{c}} \text {-változás }} \\
\text { (vs. placebo) a 26. héten }\end{array}$ \\
\hline Életkor átlaga (év) & 42 & 42,7 & 45 & 43 \\
\hline Diabetestartam átlaga (év) & 20 & 19,3 & 22 & 21 \\
\hline Inzulinterápia & $40 \%$ pumpa, $60 \% \mathrm{MDI}$ & $34 \%$ pumpa, $66 \% \mathrm{MDI}$ & $40 \%$ pumpa, $60 \% \mathrm{MDI}$ & $34 \%$ pumpa, $66 \% \mathrm{MDI}$ \\
\hline $\mathrm{HbA}_{1 \mathrm{c}}$ kiinduláskor & $8,5 \%$ & $8,4 \%$ & $8,1 \%$ & $8,2 \%$ \\
\hline $\begin{array}{c}\text { Beválasztási eGFR- } \\
\text { kritérium }\end{array}$ & $\geq 60 \mathrm{ml} / \mathrm{min} / 1,73 \mathrm{~m}^{2}$ & $\geq 60 \mathrm{ml} / \mathrm{min} / 1,73 \mathrm{~m}^{2}$ & $\geq 30 \mathrm{ml} / \mathrm{min} / 1,73 \mathrm{~m}^{2}$ & $\geq 30 \mathrm{ml} / \mathrm{min} / 1,73 \mathrm{~m}^{2}$ \\
\hline
\end{tabular}

* az elsődleges végpontot a 24. hétnél értékelték

** az elsődleges végpontot a 26. hétnél értékelték 
2. táblázat. A DEPICT (dapagliflozin vs. placebo) és az EASE (empagliflozin vs. placebo) vizsgálatok fontosabb eredményei (hatás, mellékhatás - a 24. hétnél [DEPICT], illetve a 26. hétnél [EASE] megfigyelt adatok)

A hatást feltüntető számszerü adatok átlagértékek, az aktiv ágon és placebo ágon megfigyelt, a kiindulási helyzethez viszonyított változás különbsége.

\begin{tabular}{|c|c|c|c|c|}
\hline & DEPICT-1 & DEPICT-2 & EASE-2 & EASE-3 \\
\hline $\mathrm{HbA}_{1 \mathrm{c}}$ változása & $\begin{array}{l}\text { DAPA } 5 \mathrm{mg}:-0,42 \%^{*} \\
\text { DAPA } 10 \mathrm{mg}:-0,45 \%^{*}\end{array}$ & $\begin{array}{l}\text { DAPA } 5 \mathrm{mg}:-0,37 \%^{*} \\
\text { DAPA } 10 \mathrm{mg}:-0,42 \% *\end{array}$ & $\begin{array}{l}\text { EMPA } 10 \mathrm{mg}:-0,54 \% * \\
\text { EMPA } 25 \mathrm{mg}:-0,53 \%^{*}\end{array}$ & $\begin{array}{l}\text { EMPA } 2,5 \mathrm{mg}:-0,28 \% * \\
\text { EMPA } 10 \mathrm{mg}:-0,45 \% * \\
\text { EMPA } 25 \mathrm{mg}:-0,52 \% *\end{array}$ \\
\hline Testsúly változása & $\begin{array}{l}\text { DAPA } 5 \mathrm{mg}:-2,96 \%^{*} \\
\text { DAPA } 10 \mathrm{mg}:-3,72 \%^{*}\end{array}$ & $\begin{array}{l}\text { DAPA } 5 \text { mg: }-3,21 \% * \\
\text { DAPA } 10 \text { mg: }-3,74 \% *\end{array}$ & $\begin{array}{l}\text { EMPA } 10 \mathrm{mg}:-2,7 \mathrm{~kg}^{*} \\
\text { EMPA } 25 \mathrm{mg}:-3,3 \mathrm{~kg}^{*}\end{array}$ & $\begin{array}{l}\text { EMPA } 2,5 \mathrm{mg}:-1,8 \mathrm{~kg}^{*} \\
\text { EMPA } 10 \mathrm{mg}:-3,0 \mathrm{~kg}^{*} \\
\text { EMPA } 25 \mathrm{mg}:-3,4 \mathrm{~kg}^{*}\end{array}$ \\
\hline Inzulin-összdózis változása & $\begin{array}{l}\text { DAPA } 5 \mathrm{mg}:-8,8 \% * \\
\text { DAPA } 10 \mathrm{mg}:-13,2 \% *\end{array}$ & $\begin{array}{l}\text { DAPA } 5 \text { mg: }-10,7 \% * \\
\text { DAPA } 10 \mathrm{mg}:-11,0 \% *\end{array}$ & $\begin{array}{l}\text { EMPA } 10 \mathrm{mg}:-13,3 \%^{*} \\
\text { EMPA } 25 \mathrm{mg}:-12,7 \%^{*}\end{array}$ & $\begin{array}{l}\text { EMPA } 2,5 \mathrm{mg}:-6,4 \%^{*} \\
\text { EMPA } 10 \mathrm{mg}:-9,5 \% * \\
\text { EMPA } 25 \mathrm{mg}:-12,6 \% *\end{array}$ \\
\hline Genitális infekció $(\geq 1)$ & $\begin{array}{c}\text { PBO: } 7(3 \%) \\
\text { DAPA } 5 \mathrm{mg}: 34(12 \%) \\
\text { DAPA } 10 \mathrm{mg}: 33(11 \%)\end{array}$ & $\begin{array}{c}\text { PBO: } 5(1,8 \%) \\
\text { DAPA } 5 \mathrm{mg}: 27(10 \%) \\
\text { DAPA } 10 \mathrm{mg}: 21(7,8 \%)\end{array}$ & \multicolumn{2}{|c|}{$\begin{array}{l}\text { EASE-2 és EASE-3 együtt értékelve: } \\
\text { EMPA } 25 \text { mg: 14,3\%; EMPA } 10 \text { mg: 12,8\%; PBO: 4,3\% } \\
\text { EASE-3 külön: EMPA 2,5 mg: 5,4\%; PBO: 2,5\% }\end{array}$} \\
\hline Súlyos hypoglykaemia $(\geq 1)$ & $\begin{array}{c}\text { PBO: } 19(7 \%) \\
\text { DAPA } 5 \mathrm{mg}: 21(8 \%) \\
\text { DAPA } 10 \mathrm{mg}: 16(6 \%)\end{array}$ & $\begin{array}{c}\text { PBO: } 21(7,7 \%) \\
\text { DAPA } 5 \mathrm{mg}: 17(6,3 \%) \\
\text { DAPA } 10 \mathrm{mg}: 23(8,5 \%)\end{array}$ & \multicolumn{2}{|c|}{$\begin{array}{l}\text { EASE-2 és EASE-3 együtt értékelve: } \\
\text { EMPA } 25 \text { mg: 2,7\%; EMPA } 10 \text { mg: 4,1\%; PBO: 3,1\% } \\
\text { EASE-3 külön: EMPA 2,5 mg: 1,2\%; PBO: } 2,5 \%\end{array}$} \\
\hline Ketoacidózis ( $\geq 1$ ) & $\begin{array}{c}\text { PBO: } 3(1 \%) \\
\text { DAPA } 5 \text { mg: } 4(2 \%) \\
\text { DAPA } 10 \mathrm{mg}: 5(2 \%)\end{array}$ & $\begin{array}{c}\text { PBO: } 0(0 \%) \\
\text { DAPA } 5 \mathrm{mg}: 7(2,6 \%) \\
\text { DAPA } 10 \mathrm{mg}: 6(2,2 \%)\end{array}$ & \multicolumn{2}{|c|}{$\begin{array}{l}\text { EASE-2 és EASE-3 együtt értékelve: } \\
\text { EMPA } 25 \text { mg: 3,3\%; EMPA } 10 \text { mg: 4,3\%; PBO: 1,2\% } \\
\text { EASE-3 külön: EMPA 2,5 mg: 0,8\%; PBO: 1,2\% }\end{array}$} \\
\hline
\end{tabular}

PBO: placebo; DAPA: dapagliflozin, EMPA: empagliflozin

* $\mathrm{p}<0,0001$ vs. placebo mellett észlelt változás

Az eredetileg randomizált 833 betegből 708 (85\%) teljesítette az 52 hetes követést. Inzulin + napi 5 mg dapagliflozin mellett (vs. placebo) a kiindulási helyzethez viszonyított $\mathrm{HbA}_{1 \mathrm{c}}$-érték $0,33 \%$-kal, a testsúly 2,95\%-kal csökkent. Inzulin + napi $10 \mathrm{mg}$ dapagliflozin mellett (vs. placebo) a $\mathrm{HbA}_{1 c}$-érték 0,36\%-kal, a testsúly 4,54\%-kal csökkent. A hypoglykaemia-események terén érdemi különbség nem volt a három csoport között. Megerősített ketoacidózis-esetek gyakrabban fordultak elő dapagliflozin $5 \mathrm{mg}(4,0 \%)$, dapagliflozin $10 \mathrm{mg}(3,4 \%)$ vs. placebo $(1,9 \%)$ mellett. A szerzők úgy foglaltak állást, hogy a dapagliflozin 1-es típusú diabetesben - az inzulinterápiához hozzáadva - javítja a glykaemiás kontrollt és csökkenti a testsúlyt, ezek a változások előnyösek és ebben a diabetestípusban figyelemre méltók. A dapagliflozin mellékhatásaira - a genitális mikotikus infekciók kialakulásának gyakoribb előfordulásán túl - tekintettel kell lenni, 1-es típusú diabetesben a ketoacidózis kialakulásának lehetőségét szem előtt kell tartani, a betegeket erről a körülményről fel kell világosítani, hogy az esetleges anyagcsere-kisiklásnak ne legyen komolyabb következménye.
A DEPICT-2 kettős vak, multicentrikus, IIIas fázisú vizsgálat terve, felépítése megegyezett a DEPICT-1 vizsgálatéval, más országokat, több beteget vontak be Észak- és Dél-Amerikából, illetve Ázsiából. Az eredményeket a 2018. évi ADAkongresszuson ismertették és szimultán a Diabetes Care hasábjain közölték. ${ }^{23}$ A vizsgálatban 18-75 év közötti, 1-es típusú diabetesben szenvedő betegek szerepeltek $\left(\mathrm{HbA}_{1 \mathrm{c}}: 7,5-10,5 \%\right)$, akik a véletlen besorolás elve alapján 1:1:1 arányban három vizsgálati ágra kerülhettek: 1) inzulin + napi $5 \mathrm{mg}$ dapagliflozin $(\mathrm{n}=271), 2)$ inzulin + napi $10 \mathrm{mg}$ dapagliflozin $(\mathrm{n}=270), 3)$ inzulin + placebo $(\mathrm{n}=272)$.

A vizsgálat tartama 52 hét, a 24 . hetes eredményeket publikálták eddig. ${ }^{23}$ Inzulin + napi $5 \mathrm{mg}$ dapagliflozin mellett (vs. placebo) a kiindulási helyzethez viszonyított $\mathrm{HbA}_{1 \mathrm{c}}$-érték $0,37 \%$-kal, a testsúly 3,21\%-kal, a napi inzulin-összdózis 10,7\%-kal csökkent $(\mathrm{p}<0,0001)$. Inzulin + napi $10 \mathrm{mg}$ dapagliflozin mellett (vs. placebo) a $\mathrm{HbA}_{1 c}$-érték $0,42 \%$ kal, a testsúly $3,74 \%$-kal, a napi inzulin-összdózis pedig 11,0\%-kal csökkent ( $\mathrm{p}<0,0001)$. A hypoglykaemiákat tekintve a csoportok között érdemi különbség nem adódott, a ketoacidózis-esetek 
gyakorisága azonban dapagliflozin mellett nőtt (dapagliflozin $5 \mathrm{mg}$ : 2,6\%, dapagliflozin $10 \mathrm{mg}$ : 2,2\%, placebo: 0,0\%) (1. és 2. táblázat). A szerzők következtetése szerint 1-es típusú diabetesben a helyzethez igazodó inzulinterápia mellett alkalmazott dapagliflozin javítja a glykaemiás kontrollt, csökkenti a testsúlyt és az inzulindózist úgy, hogy a hypoglykaemia-események száma érdemben nem nő, de a ketoacidózis-esetek gyakoribbá válnak.

A DEPICT vizsgálatok újabb ismeretekkel gyarapították a dapagliflozinnal kapcsolatos eddigi adatokat. Mindazonáltal a napi gyakorlatban 2018 végén csak 2-es típusú diabetes kezelésére használhatjuk a forgalmazott készítményt.

\section{Canagliflozin}

A canagliflozin szerepét 1-es típusú diabetesben II-es fázisú vizsgálatban tesztelték. ${ }^{24} \mathrm{Az}$ eredmények ismeretében a fejlesztésnek ezzel az irányával leálltak, a készítmény 2-es típusú diabetes kezelésére került forgalomba.

\section{Empagliflozin}

Az empagliflozin szerepét 1-es típusú diabetesben az EASE (Empagliflozin as Adjunctive to Insulin Therapy) program keretén belül vizsgálták. Az EASE1 rövid (4 hétig tartó), kevés beteggel $(n=75)$ zajló vizsgálat volt. ${ }^{25,26}$ Az EASE-2 és EASE-3 vizsgálatot nagyobb betegszámmal, 26, illetve 52 hétig folytatták, utóbbiak eredményét a 2018. évi ADAkongresszuson ismertették, az adatokat szimultán publikálták a Diabetes Care hasábjain. ${ }^{27}$

Az EASE program $(n=1707)$ két kettős vak, placebo-kontrollált, III-as fázisú vizsgálatot ölelt fel. ${ }^{27} \mathrm{Az}$ EASE-2 vizsgálatban empagliflozin $10 \mathrm{mg}$ $(\mathrm{n}=243)$, empagliflozin $25 \mathrm{mg}(\mathrm{n}=244)$ és placebo $(n=243)$ szerepelt, a követés tartama 52 hét volt, az elsődleges végpont alakulását a 26. hétnél értékelték. Az EASE-3 vizsgálatban empagliflozin $2,5 \mathrm{mg}$ $(\mathrm{n}=241), 10 \mathrm{mg}(\mathrm{n}=248), 25 \mathrm{mg}(\mathrm{n}=245)$ és placebo $(n=241)$ szerepelt, a követés tartama 26 hét volt.

A közlemény egymás mellé illesztve taglalja az EASE-2 és EASE-3 eredményeit. ${ }^{27}$ Fontos körülmény, hogy az EASE-3 vizsgálatban szerepelő 2,5 mg-os empagliflozin dózis jelentősen alacsonyabb a 2-es típusú diabetesben használatos dózisoknál (10 $\mathrm{mg}$ és $25 \mathrm{mg})$. Mindhárom empagliflozin-dózis (2,5 mg; $10 \mathrm{mg} ; 25 \mathrm{mg}$ ) statisztikailag értékelhetően csökkentette a $\mathrm{HbA}_{1 \mathrm{c}}$-értéket a 26. hétnél. A csökkenés dózisdependens volt, a maximális csökkenés $0,54 \%$ volt, de még $2,5 \mathrm{mg}$ mellett is megfigyeltek 0,28\%-os csökkenést. Előnyösen változott a testsúly, az inzulindózis, a systolés vérnyomás. Az EASE3-vizsgálatban a testsúly alakulása $-1,8 \mathrm{~kg},-3,0$ $\mathrm{kg},-3,4 \mathrm{~kg}(\mathrm{p}<0,0001)$; az inzulindózis változása $-6,4 \%,-9,5 \%,-12,6 \%(\mathrm{p}<0,0001)$; a systolés vérnyomás változása: $-2,1 \operatorname{Hgmm}(\mathrm{p}<0,05),-3,9$ Hgmm, -3,7 Hgmm ( $<<0,0001)$ volt. Empagliflozin mellett a genitális mikotikus infekciók gyakrabban fordultak elő. Ketoacidózis-esetek gyakrabban fordultak elő empagliflozin $10 \mathrm{mg}(4,3 \%)$ és empagliflozin $25 \mathrm{mg}(3,3 \%)$ mellett, de a napi $2,5 \mathrm{mg}$ mellett észlelt gyakoriság $(0,8 \%)$ összehasonlítható volt a placebo mellett megfigyelt gyakorisággal $(1,2 \%)$. Súlyos hypoglykaemia ritkán fordult elő, a gyakoriságot tekintve a csoportok között értékelhető különbség nem mutatkozott (1. és 2. táblázat).

A szerzők következtetése szerint az empagliflozin 1-es típusú diabetesben az inzulinterápiához hozzáadva javította a glykaemiás kontrollt, csökkentette a testsúlyt, de a hypoglykaemia-gyakoriságot nem növelte. A ketoacidózis-esetek gyakorisága csak $10 \mathrm{mg}$ és $25 \mathrm{mg}$ empagliflozin mellett nőtt, napi 2,5 mg mellett nem (placebóhoz viszonyítva). Nem vitás, hogy a ketocidózis fokozott kockázata komoly mellékhatásként értékelendő ebben a diabetestípusban. A vizsgálat eredményei arra utalnak, hogy a gyakoriság növekedése dózisdependens jellegü. Mindenesetre ebben a betegcsoportban fokozott figyelmet kell fordítani a ketoacidózis időben történő detektálására (társuló heveny betegségek, pumpa-elakadás felismerése, inzulindózis nagyobb csökkentésének elkerülése), hogy adott esetben a megfelelő terápiát késlekedés nélkül meg lehessen kezdeni. Az adatok értékesen bővítették ismereteinket az empagliflozinról, de nem szabad szem elől téveszteni, hogy mai tudásunk szerint a forgalomba került készítményeket csak 2-es típusú diabetesben alkalmazhatjuk.

\section{SGLT-2/SGLT-1 duális gátlása 1-es típusú diabetesben}

Az SGLT-2-gátlás a renális tubuláris glukózreabszorpció gátlása nyomán létrejövő fokozott 
glukózuria révén vezet el végül a vércukor csökkenéséhez, további más előnyös változások (testsúlyvesztés, vérnyomáscsökkenés, kardiovaszkuláris és renális kockázat csökkenése) mellett. A gyógyszerfejlesztés egyik iránya azt a célt követte, hogy minél szelektívebb SGLT-2-gátlót állítsanak elő, ezzel optimalizálva a megfelelő renális hatást. Kiderült azonban, hogy az SGLT-2-gátlás mellett jelen lévő és detektálható SGLT-1-gátlás (kevésbé szelektív SGLT-2-gátlók előállítása) további előnyöket rejthet magában. Az SGLT-1-gátlás ugyanis a proximális bélrendszerben csökkenti a glukózfelszívódást, minek következtében csökken és időben elhúzódik a postprandialis vércukoremelkedés. Nyilvánvaló, hogy ez a hatás diabetesben további előnyt jelenthet a glykaemiás kontroll elérése terén.

A duális SGLT-2/SGLT-1 gátlást biztosító készítmények között a klinikai bevezetéshez legközelebb a sotagliflozin áll. A sotagliflozin 2018 végén még nem regisztrált készítmény, de mind az Egyesült Államokban, mind Európában benyújtották a kérelmet a regisztrációra, 1-es típusú diabetesben történő alkalmazhatóság elnyerése céljából. Zajlanak azonban vizsgálatok 2-es típusú diabetesben is, ezek eredményei a közeljövőben várhatók.

A sotagliflozinnal folytatott III-as fázisú klinikai tanulmányok a hatásosság mellett a biztonságosságot is vizsgálták, ami során a potenciális mellékhatásokat tárták fel. Jellegzetes mellékhatásként a genitális mikotikus infekciók megszaporodására (az SGLT-2-gátlás következtében) és a hasmenés gyakoribbá válására (az SGLT-1-gátlással összefüggésben) számíthatunk. Cukorbetegek körében igen fontos bármely új készítmény esetében az, hogy alkalmazása során hogyan alakulnak a hypoglykaemia-események, illetve a ketoacidózis-esetek. Érthető tehát, hogy ezeket a potenciális mellékhatásokat is fokozott figyelemmel követték.

\section{Sotagliflozin}

A sotagliflozin (a fejlesztés során LX4211) 2018 végén még nem regisztrált orális antidiabetikum, adásakor SGLT-2- és SGLT-1-gátlás is megvalósul. A sotagliflozin fejlesztése során kezdetben történtek rövid tartamú klinikai vizsgálatok 2-es típusú diabetesben, de később a klinikai kutatás új irányt vett és alkalmazhatóságát 1-es típusú diabetesben kezdték vizsgálni, napjainkban a figyelem elsősorban ez utóbbi körülményre fokuszál. A kezdeti biztató eredmények után három nagy randomizált, kontrollált tanulmányban (inTandem vizsgálatok) értékelték a sotagliflozin hatékonyságát és biztonságosságát 1-es típusú diabetesben. Először az inTandem 3 vizsgálat eredményeit ismerhettük meg 2017-ben, majd az inTandem 1 és inTandem 2 vizsgálat eredményeit egyidejűleg publikálták 2018-ban a Diabetes Care hasábjain. Valamennyi vizsgálat randomizált, placebo-kontrollos, kettős vak, III-as fázisú tanulmány volt. ${ }^{28,29,30}$

$\mathrm{Az}$ inTandem3 tanulmányba 1-es típusú diabetesben szenvedő betegeket $(n=1402)$ vontak be 19 ország 133 vizsgáló helyén, az aktív ágon napi $400 \mathrm{mg}$ sotagliflozin, a kontroll ágon placebo szerepelt. ${ }^{28}$ A betegek kellő információt kaptak a ketoacidózis lehetőségéről és számukra nemcsak a vércukor-önellenőrzés, hanem vérmintából a ketonmérés lehetőségét is biztosították. A vizsgálati szer adásának megkezdésekor az étkezési inzulin 30\%-os csökkentését javasolták, majd az inzulindózist az önellenőrzési értékek alapján változtatni lehetett a későbbiekben az adott helyzetnek megfelelően. A betegek életkora (átlagértékek) 42 év, a diabetestartam 20 év, a kiindulási $\mathrm{HbA}_{1 c}$-érték $8,2 \%$ volt, $40 \%$-uk pumpakezelésben részesült, a 60\%-ukat napi többszöri inzulinadással kezelték. A követési idő 24 hét volt. Az elsődleges összetett végpont $\left(\mathrm{HbA}_{1 \mathrm{c}}<7,0 \%\right.$, súlyos hypoglykaemia vagy ketoacidózis előfordulása nélkül) a sotagliflozint kapók között nagyobb arányban volt észlelhető, mint a placebót kapók körében $(28,6 \%$ vs. $15,2 \%, \mathrm{p}<0,001$ ). Sotagliflozin (vs. placebo) mellett értékelhetően csökkentek az alábbi értékek a kiindulási helyzethez viszonyítva: $\mathrm{HbA}_{1 \mathrm{c}}$ (különbség vs. placebo $-0,46 \%$; $\mathrm{p}<0,001$ ), testsúly (különbség vs. placebo $-2,98 \mathrm{~kg} ; \mathrm{p}<0,001)$, systolés vérnyomás (különbség vs. placebo $-3,5 \mathrm{Hgmm}$; $\mathrm{p}<0,002$ ), inzulindózis (különbség vs. placebo: összdózis $-5,3 \mathrm{E} / \mathrm{nap}$, bolus dózisa $-2,8 \mathrm{E} / \mathrm{nap}$, bázis dózisa: $-2,6 \mathrm{E} / \mathrm{nap} ; \mathrm{p}<0,001)$. A hypoglykaemia-események terén összességében véve a két csoport nem különbözött egymástól, de dokumentált hypoglykaemia (vércukor $<3,1 \mathrm{mmol} / \mathrm{l}$ ) ritkábban fordult elő sotagliflozin (vs. placebo) mellett. Genitális mikotikus infekció és hasmenés gyakrabban fordult elő sotagliflozin (vs. placebo) mellett. Ketoacidózis-eset (egy vagy több ízben) gyakoribb 
volt sotagliflozin (vs. placebo) mellett (3,0\% vs. 0,6\%) (3. és 4. táblázat).

$\mathrm{Az}$ inTandem1 vizsgálatot az Egyesült Államok és Kanada 75 centrumában folytatták, 1-es típusú diabetesben szenvedő betegek körében. ${ }^{29}$ Nyolc hétre terjedő előperiódus után, optimalizált inzulinterápiát követően indították a kezelést a vizsgálati készítménnyel. A betegek életkora (átlagértékek) 46 év, a diabetestartam 24 év, a BMI $30 \mathrm{~kg} / \mathrm{m}^{2}$, a kiindulási $\mathrm{HbA}_{1 \mathrm{c}}$-érték 7,6\% volt, $60 \%$ uk pumpakezelésben részesült, a $40 \%$-ukat napi többszöri inzulinadással kezelték. Három ágra

3. táblázat. Az inTandem (sotagliflozin vs. placebo) vizsgálatok fontosabb klinikai adatai

\begin{tabular}{|c|c|c|c|}
\hline & inTandem 1 & inTandem 2 & inTandem 3 \\
\hline Alapterápia & optimalizált inzulin & optimalizált inzulin & szokásos inzulin \\
\hline Vizsgálati készítmény & $\begin{array}{c}\text { placebo, sotagliflozin } 200 \mathrm{mg} \\
\text { sotagliflozin } 400 \mathrm{mg}\end{array}$ & $\begin{array}{c}\text { placebo, sotagliflozin } 200 \mathrm{mg} \text {, } \\
\text { sotagliflozin } 400 \mathrm{mg}\end{array}$ & placebo, sotagliflozin $400 \mathrm{mg}$ \\
\hline Betegszám (n) & 793 & 782 & 1402 \\
\hline Vizsgálat tartama & 52 hét* & 52 hét* & 24 hét \\
\hline Elsődleges végpont & $\begin{array}{c}\mathrm{HbA}_{1 c} \text {-változás (vs. placebo) a } 24 . \\
\text { héten }\end{array}$ & $\begin{array}{c}\mathrm{HbA}_{1 c} \text {-változás (vs. placebo) a } 24 . \\
\text { héten }\end{array}$ & $\begin{array}{c}\mathrm{HbA}_{1 c}<7,0 \% \text {, súlyos } \\
\text { hypoglykaemia, és ketoacidózis } \\
\text { nélkül }\end{array}$ \\
\hline Életkor átlaga (év) & 46 & 41 & 42 \\
\hline Diabetestartam átlag (év) & 24 & 18 & 20 \\
\hline Inzulinterápia & $60 \%$ pumpa, $40 \% \mathrm{MDI}$ & $26 \%$ pumpa, $74 \% \mathrm{MDI}$ & $40 \%$ pumpa, $60 \% \mathrm{MDI}$ \\
\hline $\mathrm{HbA}_{1 \mathrm{c}}$ kiinduláskor & $7,6 \%$ & $7,7 \%$ & $8,2 \%$ \\
\hline Beválasztási eGFR-kritérium & $\geq 45 \mathrm{ml} / \mathrm{min} / 1,73 \mathrm{~m}^{2}$ & $\geq 45 \mathrm{ml} / \mathrm{min} / 1,73 \mathrm{~m}^{2}$ & $\geq 45 \mathrm{ml} / \mathrm{min} / 1,73 \mathrm{~m}^{2}$ \\
\hline
\end{tabular}

*az elsődleges végpontot a 24. hétnél értékelték

4. táblázat. Az inTandem (sotagliflozin vs. placebo) vizsgálatok fontosabb eredményei (hatás, mellékhatás - a 24. hétnél megfigyelt adatok)

A hatást feltüntető számszerú adatok átlagértékek, az aktiv ágon és placebo ágon megfigyelt, a kiindulási helyzethez viszonyitott változás különbsége.

\begin{tabular}{|c|c|c|c|}
\hline & inTandem 1 & inTandem 2 & inTandem 3 \\
\hline $\mathrm{HbA}_{1 \mathrm{c}}$ változása & $\begin{array}{l}\text { SOTA } 200 \mathrm{mg}:-0,36 \% * \\
\text { SOTA } 400 \mathrm{mg}:-0,41 \%^{*}\end{array}$ & $\begin{array}{l}\text { SOTA } 200 \mathrm{mg}:-0,37 \% * \\
\text { SOTA } 400 \mathrm{mg}:-0,35 \% *\end{array}$ & SOTA 400 mg: $-0,46 \% *$ \\
\hline Testsúly változása & $\begin{array}{l}\text { SOTA } 200 \mathrm{mg}:-2,4 \mathrm{~kg}^{*} \\
\text { SOTA } 400 \mathrm{mg}:-3,5 \mathrm{~kg}^{*}\end{array}$ & $\begin{array}{l}\text { SOTA } 200 \mathrm{mg}:-1,98 \mathrm{~kg}^{*} \\
\text { SOTA } 400 \mathrm{mg}:-2,58 \mathrm{~kg}^{*}\end{array}$ & SOTA $400 \mathrm{mg}:-2,98 \mathrm{~kg}^{*}$ \\
\hline $\begin{array}{c}\text { Inzulin-összdózis } \\
\text { változása }\end{array}$ & $\begin{array}{l}\text { SOTA } 200 \mathrm{mg}:-6,16 \% * \\
\text { SOTA } 400 \mathrm{mg}:-9,70 \% *\end{array}$ & $\begin{array}{l}\text { SOTA } 200 \mathrm{mg}:-8,23 \%^{*} \\
\text { SOTA } 400 \mathrm{mg}:-9,47 \%^{*}\end{array}$ & SOTA $400 \mathrm{mg}:-9,71 \% *$ \\
\hline Genitális infekció ( $\geq 1)$ & $\begin{array}{c}\text { PBO: } 9(3,4 \%) \\
\text { SOTA } 200 \mathrm{mg}: 24(9,1 \%) \\
\text { SOTA } 400 \mathrm{mg}: 34(13,0 \%)\end{array}$ & $\begin{array}{c}\text { PBO: } 6(2,3 \%) \\
\text { SOTA } 200 \mathrm{mg}: 24(9,2 \%) \\
\text { SOTA } 400 \mathrm{mg}: 29(11,0 \%)\end{array}$ & $\begin{array}{c}\text { PBO: } 15(2,1 \%) \\
\text { SOTA } 400 \mathrm{mg}: 45(6,4 \%)\end{array}$ \\
\hline Hasmenés & $\begin{array}{c}\text { PBO: } 18 \text { (6,7\%) } \\
\text { SOTA } 200 \text { mg: } 22(8,4 \%) \\
\text { SOTA } 400 \text { mg: } 27(10,3 \%)\end{array}$ & $\begin{array}{c}\text { PBO: } 9(3,5 \%) \\
\text { SOTA } 200 \mathrm{mg}: 12(4,6 \%) \\
\text { SOTA } 400 \mathrm{mg}: 19(7,2 \%)\end{array}$ & $\begin{array}{c}\text { PBO: } 16(2,3 \%) \\
\text { SOTA } 400 \mathrm{mg}: 29(4,1 \%)\end{array}$ \\
\hline Súlyos hypoglykaemia ( $\geq 1$ ) & $\begin{array}{c}\text { PBO: } 26(9,7 \%) \\
\text { SOTA } 200 \mathrm{mg}: 17(6,5 \%) \\
\text { SOTA } 400 \mathrm{mg}: 17(6,5 \%)\end{array}$ & $\begin{array}{c}\text { PBO: } 13(5,0 \%) \\
\text { SOTA } 200 \mathrm{mg}: 13(5,0 \%) \\
\text { SOTA } 400 \mathrm{mg}: 6(2,3 \%)\end{array}$ & $\begin{array}{c}\text { PBO: } 17(2,4 \%) \\
\text { SOTA } 400 \mathrm{mg}: 21(3,0 \%)\end{array}$ \\
\hline Ketoacidózis ( $\geq 1)$ & $\begin{array}{c}\text { PBO: } 1(0,4 \%) \\
\text { SOTA } 200 \mathrm{mg}: 9(3,4 \%) \\
\text { SOTA } 400 \mathrm{mg}: 11(4,2 \%)\end{array}$ & $\begin{array}{c}\text { PBO: } 0 \text { (0\%) } \\
\text { SOTA } 200 \mathrm{mg}: 6(2,3 \%) \\
\text { SOTA } 400 \mathrm{mg}: 9(3,4 \%)\end{array}$ & $\begin{array}{c}\text { PBO: } 4(0,6 \%) \\
\text { SOTA } 400 \mathrm{mg}: 21(3,0 \%)\end{array}$ \\
\hline
\end{tabular}

PBO: placebo, SOTA: sotagliflozin

${ }^{*} \mathrm{p}<0,001$ vs. placebo mellett észlelt változás 
randomizálták a betegeket: 1) sotagliflozin napi $200 \mathrm{mg}(\mathrm{n}=263), 2)$ sotagliflozin napi $400 \mathrm{mg}$ $(n=262), 3)$ placebo $(n=268)$.

Az elsődleges végpontot $\left(\mathrm{HbA}_{1 c}\right.$-csökkenés mértéke a kiindulási helyzethez viszonyítva, a placebóval szembeni különbség értékében megadva) a 24. hétnél értékelték, de a vizsgálatot kiterjesztették további 28 hétre, azaz a követés teljes tartama 52 hét volt. Sotagliflozin $200 \mathrm{mg}$ és sotagliflozin $400 \mathrm{mg}$ (vs. placebo) mellett értékelhetően jobban csökkent a $\mathrm{HbA}_{1 \mathrm{c}}$ értéke a 24. héten, a kiindulási helyzethez viszonyítva (különbség vs. placebo $-0,36 \%$ és $-0,41 \%$; $\mathrm{p}<0,001$ ), a különbség az 52 . hétre valamelyest mérséklődött, de továbbra is szignifikáns maradt $(-0,25 \%$ és $-0,31 ; p<0,001)$. $\mathrm{Az}$ 52. héten $400 \mathrm{mg}$ sotagliflozin (vs. placebo) mellett a testsúlycsökkenés $-4,32 \mathrm{~kg}$ volt, a bolusinzulin dózisa $-15,63 \%$-kal, a bázisinzulin dózisa $-11,87 \%$-kal csökkent $(\mathrm{p}<0,001)$. A betegek egy csoportjában szöveti glukózmonitorozást is végeztek, ami a glukózvariabilitás csökkenését igazolta sotagliflozin mellett. Külön értékelték azokat a betegeket, akiknél a 24. hétre a $\mathrm{HbA}_{1 \mathrm{c}}$ értéke 7\% alá csökkent úgy, hogy nem fordult elő súlyos hypoglykaemia vagy ketoacidózis, a gyakoriság az alábbi volt: $200 \mathrm{mg}$ sotagliflozin $33,4 \%$, $400 \mathrm{mg}$ sotagliflozin $43,5 \%$, placebo $21,6 \%$ ( $<<0,001)$. Sotagliflozin mellett gyakoribb volt a ketoacidózis és a hasmenés. Szakértők által megerősített ketoacidózis-eset sotagliflozin $200 \mathrm{mg}$ mellett 3,4\%-ban, $400 \mathrm{mg}$ mellett 4,2\%-ban fordult elö, szemben a placebo ágon megfigyelt 0,4\%-os elöfordulási gyakorisággal. Súlyos hypoglykaemiát 6,5\%-ban regisztráltak mindkét sotagliflozin ágon, a placebo karon ez 9,7\% gyakorisággal volt megfigyelhető. Összességében véve a vizsgálat során sotagliflozin (vs. placebo) mellett csökkent a $\mathrm{HbA}_{1 \mathrm{c}}$-érték, a testsúly, az inzulindózis és a súlyos hypoglykaemia-események aránya, a ketoacidózis-eseteké viszont növekedett (3. és 4. táblázat). A szerzők következtetése szerint a sotagliflozin-terápia számos kedvező tulajdonsággal rendelkezik 1-es típusú diabetesben, a kockázat/előny arány elfogadható.

$\mathrm{Az}$ inTandem 2 vizsgálat protokollja azonos volt az inTandem 1 vizsgálatéval, a tanulmányt Európa országaiban és Izraelben folytatták. ${ }^{30}$ A fontosabb alapadatokat, az eredményeket (hatás/mellékhatás) a 3. és 4. táblázat részletezi, azok egybecsengtek az inTandem 1 vizsgálatban megfigyeltekkel, a szerzők következtetései is lényegében véve azonosak a korábbiakkal.

\section{Összefoglalás}

Láthatóan és érthetően nagy az érdeklődés, hogy az SGLT-2-gátló készítmények (dapagliflozin, empagliflozin), illetve a duális SGLT-2/SGLT-1-gátlást egyaránt megvalósító sotagliflozin alkalmazhatók-e 1-es típusú diabetesben a jelenleg szokásos inzulinterápia mellett. Az alapvető kérdés az, hogy az adott készítménynek igazolható-e kedvező hatása és az előny felülmúlja-e a kockázatot ebben a diabetes-típusban.

A részletezett vizsgálatok és a közlemények szerzőinek véleménye szerint az előnyös hatás nem kétséges 1-es típusú diabetesben sem, hiszen - placebóhoz viszonyítva - az SGLT-gátlók szignifikánsan csökkentik a $\mathrm{HbA}_{1 \mathrm{c}}$-értéket, javítják a glykaemiás kontroll egyéb paramétereit, csökkentik a testsúlyt, a vérnyomást és az inzulindózis is csökkenthetőnek bizonyult. Ezeket a megfigyeléseket metaanalízis is megerősítette. ${ }^{31}$ A hypoglykaemia-kockázat több vizsgálatban nem nőtt. Mindezek olyan kedvező tulajdonságok, amelyeket érdemes lenne kiaknázni az 1-es típusú diabetesben szenvedők kezelése során. A kérdés az, hogy mi a kezelés kockázata és az hogyan viszonyul a várható előnyhöz. Kockázatként az SGLT-2-gátlók jól ismert mellékhatását, a genitális mikotikus infekciók gyakoriságának növekedését kell elsősorban számba venni. Ez a potenciális mellékhatás kellemetlen, de tulajdonképpen nem veszélyes, adott esetben kezelhető, s emiatt ritkán kényszerülünk az adott készítmény adásának felfüggesztésére. Sotagliflozin adásakor a hasmenés jelentkezése (amely a leírás szerint enyhe és átmeneti) szintén a kellemetlen, de nem veszélyes mellékhatások közé tartozik. Komoly kockázati tényezőként a ketoacidózis-esetek növekedése tartható számon, miután ezek a nemkívánatos események olykor súlyos klinikai formában is jelentkezhetnek. Nem véletlen, hogy az ismertetett tanulmányokban ebben a vonatkozásban a vizsgáló centrumokat és a bevont betegeket előre felvilágosították, és nemcsak vércukormérővel, hanem ketontest-meghatározásra alkalmas készülékkel is ellátták őket. Az áttekintett vizsgálatokban minden esetben nőtt 
a ketoacidózis-esetek aránya a placebóval kezeltek csoportjához viszonyítva.

Jelenleg (2019 elején) nem lehet megítélni, hogy ezen a téren mit hoz a közeljövő. Úgy látszik, hogy 1-es típusú diabetesben a dapagliflozin és a sotagliflozin (gyári neve: Zynquista ${ }^{\circledR}$ ) áll közel a regisztrációhoz (a szükséges dokumentumokat 2018-ban benyújtották az FDA-nak és az Európai Gyógyszerügynökségnek). A szakmai közvélemény érdeklődéssel várja az illetékes hatóságok döntését.

A napi gyakorlatot tekintve semmiképpen nem szabad megfeledkeznünk arról, hogy a hazánkban forgalmazott összes SGLT-2-gátló készítmény csak 2-es típusú diabetesben szenvedők kezelésére fogadták be a hatóságok, ezen a téren az érvényes alkalmazási előírások egyértelműen fogalmaznak, s azoktól a gyakorló orvosoknak nem szabad eltérni.

\section{Irodalom}

1. Lund SS, Tarnow L, Astrup AS, Hovind P, Jacobsen PK, Alibegovic AC, et al:: Effect of adjunct metformin treatment in patients with type-1 diabetes and persistent inadequate glycaemic control. A randomized study. PLoS One 2008; 3(10): e3363. doi:10.1371/journal.pone.0003363

2. Nádas J, Putz Z, Fövényi J, Gaál Z, Gyimesi A, Hídvégi T, et al.: Cardiovascular risk factors characteristic for the metabolic syndrome in adult patients with type 1 diabetes. Exp Clin Endocrinol Diabetes 2009; 117: 107-112. doi: $10.1055 / 5-0028-1082068$

3. Priya $G$, Kalra S: A review of insulin resistance in type 1 diabetes: is there a place for adjunctive metformin? Diabetes Ther 2018; 9: 349-361. doi:10.1007/s13300-017-0333-9

4. Petrie JR, Chaturvedi N, Ford I, Brouwers MCGJ, Greenlaw N, Tillin T, et al.; REMOVAL Study Group: Cardiovascular and metabolic effects of metformin in patients with type 1 diabetes (REMOVAL): a double-blind, randomised, placebo-controlled trial. Lancet Diabetes Endocrinol 2017; 5: 597-609. doi:10.1016/52213-8587(17)30194-8

5. Sels JP, Verdonk HE, Wolffenbuttel BH: Effects of acarbose (Glucobay) in persons with type 1 diabetes: a multicentre study. Diabetes Res Clin Pract 1998; 41: 139-145.

6. Rabasa-Lhoret R, Burelle Y, Ducros F, Bourque J, Lavoie C, Massicotte D, et al.: Use of an alpha-glucosidase inhibitor to maintain glucose homoeostasis during postprandial exercise in intensively treated Type 1 diabetic subjects. Diabet Med 2001; 18: 739-744.

7. Strowig SM, Raskin P: The effect of rosiglitazone on overweight subjects with type 1 diabetes. Diabetes Care 2005; 28: 1562-1567. doi:10.2337/diacare.28.7.1562

8. Stone ML, Walker JL, Chisholm D, Craig ME, Donaghue KC, Crock P, et al.: The addition of rosiglitazone to insulin in adolescents with type 1 diabetes and poor glycaemic control: a randomized-controlled trial. Pediatr Diabetes 2008; 9(4 Pt 1): 326-334. doi:10.1111/j.1399-5448.2008.00383.x

9. Bhat R, Bhansali A, Bhadada S, Sialy R: Effect of pioglitazone therapy in lean type 1 diabetes mellitus. Diabetes Res Clin Pract 2007; 78: 349-354. doi:10.1016/j.diabres.2007.04.012

10. Hari Kumar KV, Shaikh A, Prusty P: Addition of exenatide or sitagliptin to insulin in new onset type 1 diabetes: a randomized, open label study. Diabetes Res Clin Pract 2013; 100: e55-58. doi:10.1016/j.diabres.2013.01.020

11. Zhao Y, Yang L, Xiang Y, Liu L, Huang G, Long Z, et al:: Dipeptidyl peptidase 4 inhibitor sitagliptin maintains $\beta$-cell function in patients with recent-onset latent autoimmune diabetes in adults: one-year prospective study. I Clin Endocrinol Metab 2014; 99: E876-880. doi:10.1210/j.2013-3633

12. Mathieu C, Zinman B, Hemmingsson JU, Woo V, Colman P, Christiansen E, et al.; ADJUNCT ONE Investigators: Efficacy and safety of liraglutide added to insulin treatment in type 1 diabetes: The ADJUNCT ONE treat-to-target randomized trial. Diabetes Care 2016; 39: 1702-1710. doi:10.2337/dc16-0691

13. Munir KM, Davis SN: The treatment of type 1 diabetes mellitus with agents approved for type 2 diabetes mellitus. Expert Opin Pharmacother 2015; 16 : 2331-2341. doi:10.1517/14656566.2015.1084502

14. DeGeeter $M$, Williamson B: Alternative agents in type 1 diabetes in addition to insulin therapy: metformin, alpha-glucosidase inhibitors, pioglitazone, GLP-1 agonists, DPP-IV inhibitors, and SGLT-2 inhibitors. J Pharm Pract 2016; 29: 144-159. doi:10.1177/0897190014549837

15. Warnes $\mathrm{H}$, Helliwell R, Pearson SM, Ajjan RA: Metabolic control in type 1 diabetes: is adjunctive therapy the way forward? Diabetes Ther 2018; 9 : 1831-1851. doi:10.1007/s13300-018-0496-z

16. Frandsen CS, Dejgaard TF, Madsbad S, Holst JJ: Non-insulin pharmacological therapies for treating type 1 diabetes. Expert Opin Pharmacother 2018; 19: 947-960. do: $10.1080 / 14656566.2018 .1483339$ 
17. Dellepiane S, Ben Nasr M, Assi E, Usuelli V, Letizia T, D'Addio F, et al.: Sodium glucose cotransporters inhibitors in type 1 diabetes. Pharmacol Res 2018; 133: 1-8. doi:10.1016/j.phrs.2018.04.018

18. Fattah H, Vallon V: The potential role of SGLT2 inhibitors in the treatment of type 1 diabetes mellitus. Drugs 2018; 78: $717-726$ doi:10.1007/s40265-018-0901-y

19. Tosur M, Redondo MJ, Lyons SK: Adjuvant pharmacotherapies to insulin for the treatment of type 1 diabetes. Curr Diab Rep 2018; 18(10): 79 . doi:10.1007/s11892-018-1041-1

20. McCrimmon RJ, Henry RR: SGLT inhibitor adjunct therapy in type 1 diabetes. Diabetologia 2018; 61: 2126-2133. doi:10.1007/s00125-018-4671-6

21. Dandona P, Mathieu C, Phillip M, Hansen L, Griffen SC, Tschöpe D, et al.; DEPICT-1 Investigators: Efficacy and safety of dapagliflozin in patients with inadequately controlled type 1 diabetes (DEPICT-1): 24 week results from a multicentre, double-blind, phase 3, randomised controlled trial. Lancet Diabetes Endocrinol 2017; 5: 864-876. Erratum in: Lancet Diabetes Endocrinol 2017; 5(12): e8. doi:10.1016/52213-8587(17)30308-X

22. Dandona P, Mathieu C, Phillip M, Hansen L, Tschöpe $D$, Thorén F, et al. DEPICT-1 Investigators: Efficacy and safety of dapagliflozin in patients with inadequately controlled type 1 diabetes: The DEPICT-1 52-week study. Diabetes Care 2018; 41: 2552-2559. doi:10.2337/dc18-1087

23. Mathieu C, Dandona P, Gillard $P$, Senior $P$, Hasslacher $C$, Araki $E$, et al.; DEPICT-2 Investigators: Efficacy and safety of dapagliflozin in patients with inadequately controlled type 1 diabetes (the DEPICT-2 Study): 24 week results from a randomized controlled trial. Diabetes Care 2018; 41 : 1938-1946. doi:10.2337/dc18-0623

24. Henry RR, Thakkar P, Tong C, Polidori D, Alba M: Efficacy and safety of canagliflozin, a sodium-glucose cotransporter 2 inhibitor, as add-on to insulin in patients with type 1 diabetes. Diabetes Care 2015; 38: 2258-2265. doi: $10.2337 / d c 15-1730$

25. Pieber TR, Famulla S, Eilbracht J, Cescutti J, Soleymanlou N, Johansen OE, et al:: Empagliflozin as adjunct to insulin in patients with type 1 diabetes: a 4-week, randomized, placebo-controlled trial (EASE-1). Diabetes Obes Metab 2015; 17: 928-935. doi:10.1111/dom.12494
26. Famulla S, Pieber TR, Eilbracht J, Neubacher D, Soleymanlou N, Woerle HJ, et al.: Glucose exposure and variability with empagliflozin as adjunct to insulin in patients with type 1 diabetes: continuous glucose monitoring data from a 4-week, randomized, placebo-controlled trial (EASE-1). Diabetes Technol Ther 2017; 19: 49-60. doi:10.1089/dia.2016.0261

27. Rosenstock J, Marquard J, Laffel LM, Neubacher D, Kaspers S, Cherney DZ, et al.: Empagliflozin as adjunctive to insulin therapy in type 1 diabetes: The EASE trials. Diabetes Care 2018; 41: 2560-2569. doi:10.2337/dc18-1749

28. Garg SK, Henry RR, Banks P, Buse JB, Davies MJ, Fulcher GR, et al.: Effects of sotagliflozin added to insulin in patients with type 1 diabetes. N Engl I Med 2017; 377:2337-2348. doi:10.1056/NEJMoa1708337

29. Buse JB, Garg SK, Rosenstock J, Bailey TS, Banks P, Bode BW, et al.: Sotagliflozin in combination with optimized insulin therapy in adults with type 1 diabetes: The North American inTandem1 Study. Diabetes Care 2018; 41: 1970-1980. doi:10.2337/dc18-0343

30. Danne T, Cariou B, Banks P, Brandle M, Brath H, Franek E, et al.: HbA and hypoglycemia reductions at 24 and 52 weeks with sotagliflozin in combination with insulin in adults with type 1 diabetes: The European inTandem2 Study. Diabetes Care 2018; 41: 1981-1990. doi: $10.2337 / \mathrm{dc} 18-0342$

31. El Masri D, Ghosh S, Jaber LA: Safety and efficacy of sodium-glucose cotransporter 2 (SGLT2) inhibitors in type 1 diabetes: A systematic review and meta-analysis. Diabetes Res Clin Pract 2018; 137: 83-92. doi:10.1016/j.diabres.2018.01.004

Közlésre érkezett: 2019. február 9.

Közlésre elfogadva: 2019. május 16.

\section{A szerzö levelezési címe:}

Prof. Dr. Jermendy György

Bajcsy-Zsilinszky Kórház és Rendelőintézet

1106 Budapest, Maglódi út 89-91.

E-mail: gyjermendy@gmail.com 